\title{
IBM KELOMPOK TANI LIDAH BUAYA
}

\author{
Sri Rahayu Prastyaningsih ${ }^{1)}$, AmbarTri Ratnaningsih ${ }^{2)}$ Dedi Zargustin ${ }^{3)}$ \\ ${ }^{1}$ Fakultas Kehutanan,Universitas Lancang Kuning \\ srirahayupn@unilak..ac.id \\ ${ }^{2}$ Fakultas Kehutanan, Universitas Lancang Kuning \\ ambar_trn@yahoo.co.id \\ ${ }^{3}$ Fakultas Pertanian,Universitas Lancang Kuning \\ dedizargustin@yahoo.co.id
}

\begin{abstract}
The cultivation of aloe vera plants began since residents in Pekanbaru know of the benefits of aloe vera plant. The group of Lidah Buaya Kita was formed in January 2014 in the District Rumbai, Pekanbaru City, Riau Province. The first time, farmers only sell seedling and leaves of aloe vera, then they make crackers and tea from leaves its own garden, where product of crackers and tea can add value to the business as one of product processed of the aloe vera plant. Partners also requested training for make drinks aloe vera. The aims of this IBM (1) make drinks aloe vera (2) techniques of processing crackers use machine flour mixer (3) Products get permits from the Dinas Kesehatan (4) analyze the nutrients and chemical of crackers and tea product (5) Make packaging of drinks, crackers and tea aloe vera (6) the promotion and marketing of aloe vera products (7) business analysis of product.

IbM was implemented in 2016. Our Patners was aloe vera farmers in (1) RW 02 kelurahan Lembah Damai (2) RW 04 kelurahan Lembah Sari. The result of our IbM was (1) the partner be able to make a drink aloe vera. (2) partners have cup sealer and flour mixer machine to support their production. (3) partner has the brand, license P-IRT and test nutrient/chemical content (4) the partner is able to package the aoe vera product and ready for market (5) partners can promote aloe vera product.

The cultivation of aloe vera plants began since residents in Pekanbaru know of the benefits of aloe vera plant. The group of Lidah Buaya Kita was formed in January 2014 in the District Rumbai, Pekanbaru City, Riau Province. The first time, farmers only sell seedling and leaves of aloe vera, then they make crackers and tea from leaves its own garden, where product of crackers and tea can add value to the business as one of product processed of the aloe vera plant. Partners also requested training for make drinks aloe vera. The aims of this IBM (1) make drinks aloe vera (2) techniques of processing crackers use machine flour mixer (3) Products get permits from the Dinas Kesehatan (4) analyze the nutrients and chemical of crackers and tea product (5) Make packaging of drinks, crackers and tea aloe vera (6) the promotion and marketing of aloe vera products (7) business analysis of product.

IbM was implemented in 2016. Our Patners was aloe vera farmers in (1) RW 02 kelurahan Lembah Damai (2) RW 04 kelurahan Lembah Sari. The result of our IbM was (1) the partner be able to make a drink aloe vera. (2) partners have cup sealer and flour mixer machine to support their production. (3) partner has the brand, license P-IRT and test nutrient/chemical content (4) the partner is able to package the aoe vera product and ready for market (5) partners can promote aloe vera product.
\end{abstract}

Key Words : Farmer groups, a drink, crackers and tea. 


\section{PENDAHULUAN}

Pada saat ini, budidaya tanaman lidah buaya di Kota Pekanbaru mulai berkembang seiring dengan meningkatnya pengetahuan masyarakat terhadap khasiat tanaman untuk kesehatan. Kondisi ini dibuktikan telah dibentuknya beberapa kelompok tani yang membudidayakan tanaman lidah buaya. Kelompok Tani Lidah Buaya Kita dibentuk pada bulan Januari 2014 di kecamatan Rumbai Pesisir Kota Pekanbaru Provinsi Riau. Kelompok Tani Lidah Buaya Kita terbagi dalam kelompok-kelompok kecil setingkat RW dan Kelompok Tani yang sudah terbentuk adalah Kelompok Tani Lidah Buaya Kita RW 02, Kelurahan Lembah Damai (ketua ibu Nurhayati) dan Kelompok Tani Lidah Buaya Kita RW 04, Kelurahan Lembah Sari (ketua bapak Irnal Helmi). Masing- masing kelompok terdiri dari 15 orang yang membudidayakan tanaman lidah buaya di pekarangan rumah masing-masing. Pelepah lidah buaya dipanen 2 (dua) kali dalam sebulan dan dijual dengan harga Rp.5.000,- sd Rp.7.000,- /kg. Dengan kualitas yang sama, harga ini masih jauh di bawah harga rata-rata yang dijual di toserba atau swalayan yang berkisar Rp. 10.000,- sd Rp. 15.000,- per kg. Dalam satu rumah, sekali panen rata-rata \pm 60 batang atau $60 \mathrm{~kg}$ sehingga dalam sebulan pendapatan dari penjualan pelepah lidah buaya sekitar Rp. 600.000,- sd Rp. 840.000,- per bulan. Tanaman lidah buaya tidak memerlukan perawatan dan pemeliharaan khusus, cukup dengan campuran tanah dan pupuk kandang dengan perbandingan $1: 3$. Pelepah lidah buaya dapat dipanen pada umur 6 bulan dan selanjutnya tanaman dapat bertahan sampai 2 tahun.

Kelompok Tani Lidah Buaya Kita semula hanya menjual bibit dan pelepah lidah buaya, sekarang sudah berkembang menjadi usaha kerupuk lidah buaya dan teh lidah buaya. Lidah buaya sebagai bahan utama pembuatan kerupuk dan teh bersumber dari kebun lidah buaya milik sendiri sehingga menjadi nilai tambah bagi usaha pembibitan dan pelepah sebagai bahan baku bermacam-macam produk dari lidah buaya. Dari $1 \mathrm{~kg}$ gel lidah buaya dapat menghasilkan $1 \mathrm{~kg}$ kerupuk dan limbah kulit lidah buaya dimanfaatkan sebagai teh kesehatan. Pengolahan lidah buaya menjadi kerupuk dan teh lidah buaya dilakukan pada skala rumah tangga dengan teknologi sederhana sehingga kapasitas produksi yang dihasilkan belum maksimal. Kemampuan tenaga kerja terbatas yaitu satu orang hanya mampu mengaduk $4 \mathrm{~kg}$ dalam sekali adonan. Dalam mengolah adonan tepung juga membutuhkan waktu yang cukup lama yaitu \pm 2 jam. Mitra belum menghitung usaha kerupuk dan teh lidah buaya secara rinci sehingga keuntungan yang diperoleh masih berupa perhitungan kasar dengan mengabaikan faktor modal dan tenaga kerja.

Produk kerupuk dan teh Lidah Buaya Kita dikemas pada plastik dan belum mempunyai label atau "merk dagang" dan ijin dari BP POM, sehingga pemasarannya masih terbatas di lingkungan masyarakat sekitar dan kabupaten terdekat di Provinsi Riau seperti Bengkalis dan Kampar. Oleh karena itu, diperlukan bimbingan mengenai analisis usaha baik dari segi teknis maupun finansial agar mitra mendapatkan pendapatan dan keuntungan yang maksimal.

Kelompok Tani "Lidah Buaya Kita" juga mempunyai keinginan dan semangat untuk mengembangkan produk-produk selain kerupuk dan teh. Minuman Lidah Buaya merupakan produk yang diminati karena melihat prospek penjualan minuman segar yang ada di kota Pekanbaru.

\section{METODE PENELITIAN}

\section{a. Pelatihan membuat minuman lidah} buaya.

Besarnya minat pasar akan minuman segar di kota Pekanbaru menumbuhkan ide Kelompok Tani Lidah Buaya Kita untuk membuat minuman lidah buaya.

Pelatihan membuat minuman lidah buaya dilaksanakan pada tanggal 27 April 2016 bertempat di Kelompok Tani Lidah Buaya RW 02 Kelurahan Lembah Damai, Kecamatan Rumbai Pesisir, Kota Pekanbaru, Provinsi Riau. Mitra diberikan pelatihan membuat minuman lidah buaya dengan cara ceramah dan 
demonstrasi. Penyuluhan dalam bentuk ceramah diberikan kepada mitra dengan materi teknis pembuatan minuman lidah buaya yaitu bahan, peralatan dan cara pembuatannya selanjutnya dilakukan demonstrasi pembuatan minuman lidah buaya.

- Cara membuat minuman lidah buaya adalah sebagai berikut :

a. Bahan yang diperlukan : 1 pelepah lidah buaya berat $1 \mathrm{~kg}, 6$ buah siwalan atau 150 gram sari kelapa dipotong-potong, es batu secukupnya.

b. Rendaman : 1 liter air, $1 \mathrm{sdm}$ kapur sirih, 1 sdt garam.

c. Sirop : 350 gram gula pasir, $750 \mathrm{ml}$ air, $1 / 2$ sdt vanili bubuk, 2 lembar daun pandan, simpulkan, sirup/esens secukupnya.

d. Cara membuat :

- Rendaman : mencampur air dengan air kapur sirih dan garam.

- Mengupas pelepah lidah buaya, potong daging lidah buaya ukuran dadu $1 \mathrm{~cm}$, masukkan ke dalam air rendaman, diamkan selama 30 menit sd $1 \mathrm{jam}$, dicuci bersih dan ditiriskan.

- Memasak air hingga mendidih dan merebus daging lidah buaya selama 10 menit, kemudian diangkat.

- Sirup : Memasak air bersama gula pasir, vanili bubuk dan daun pandan, beri pewarna merah masak hingga mendidih. Masukkan daging lidah buaya dan siwalan/sari kelapa, masak sebentar, angkat dan dinginkan, simpan dalam lemari pendingin.

- Menyiapkan gelas dan diberi es batu, sirup dan lidah buaya secukupnya..

\section{b. Demostrasi teknologi produksi.}

Untuk meningkatkan kualitas dan kuantitas produk kerupuk lidah buaya, mitra mendapatkan bantuan peralatan berupa mesin pengaduk tepung. Mitra diberikan pelatihan mengenai cara pengolahan kerupuk lidah buaya dengan menggunakan mesin pengaduk tepung.

\section{c. Penyuluhan P-IRT dan kandungan} gizi
Penyuluhan dan sosialisasi mengenai pendaftaran produk ke Dinas Kesehatan. Pada kemasan juga dicantumkan hasil hasil analisis laboratorium berupa kandungan gizi dan kimia. Uji laboratorium di lakukan di Laborarium Pengembangan Teknologi Agro dan Biomedik BPPT Serpong, Banten.

\section{d. Pelatihan pengemasan dan promosi produk.}

Mitra diberikan bantuan mesin cup sealer untuk memudahkan mengemas minuman lidah buaya, sedangkan pada kemasan kerupuk dan teh lidah buaya, tim IbM memberikan contoh design kemasan dan mitra memilih sesuai dengan kemasan yang diinginkan. Setelah kemasan siap cetak maka dilakukan pelatihan mengenai teknik pengemasan produk.Selanjutnya pengusul memberikan pengetahuan kepada mitra tentang strategi pemasaran produk.

\section{e. Pelatihan Analisis Usaha}

Pelatihan analisis usaha ini dilakukan dengan cara memberi pengetahuan kepada mitra dalam menghitung komponen biaya dan penetapan harga pokok sehingga diketahui keuntungan yang diperoleh.

\section{f. Pendampingan dan Evaluasi}

Tim Ibm melakukan monitoring dan pendampingan agar usaha dapat berjalan sesuai dengan rencana. Apabila ada permasalahan mitra, maka dicarikan solusi untuk mengatasinya. Evaluasi dilakukan pada setiap kegiatan melalui pemberian kuisioner sebelum dan sesudah pelatihan.

\section{HASIL DAN PEMBAHASAN}

a. Pelatihan membuat minuman lidah buaya

Pelatihan membuat minuman lidah buaya dilaksanakan pada tanggal 27 April 2016 bertempat di Kelompok Tani Lidah Buaya RW 02 Kelurahan Lembah Damai, Kecamatan Rumbai Pesisir, Kota Pekanbaru, Provinsi Riau. Mitra diberikan pelatihan membuat minuman lidah buaya dengan cara ceramah dan demonstrasi. Penyuluhan dalam bentuk ceramah diberikan kepada mitra dengan materi teknis pembuatan minuman lidah buaya yaitu bahan, peralatan dan cara pembuatannya selanjutnya 
dilakukan demonstrasi pembuatan minuman lidah buaya.

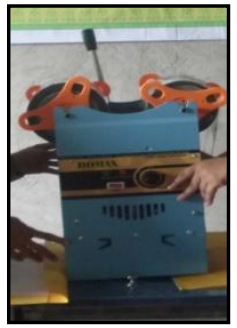

Gambar 1. Bantuan mesin pengepres gelas

\section{b. Demostrasi teknologi produksi.}

Produk kerupuk lidah buaya dikerjakan dengan tangan sehingga untuk membuat adonan yang rata (atau homogen) memerlukan waktu yang cukup lama. Dalam satu kali produksi, satu tenaga kerja hanya mampu mengaduk adonan $4 \mathrm{~kg}$ kerupuk mentah lidah buaya dengan waktu \pm 2 jam.

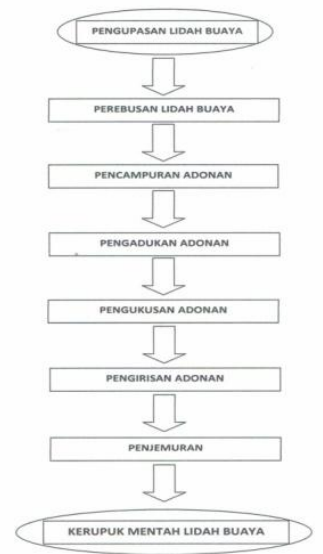

Gambar 2. Tahapan pembuatan kerupuk lidah buaya

Proses pengadukan yang cukup lama menyebabkan kerupuk yang diproduksi terbatas, sehingga diperlukan mesin pengaduk tepung. Oleh karena itu, tim IbM memberikan bantuan berupa mesin pengaduk tepung. Mesin ini mampu mengaduk adonan 3 x lipat dengan waktu $\pm 0,5 \mathrm{jam}$. Alat pengaduk tepung tersebut dicoba oleh mitra dengan bantuan tenaga ahli/teknisi mesin. Cara keja mesin adonan tepung yaitu :

- Bahan adonan kerupuk ( perbandingan 1 $\mathrm{kg}$ tepung terigu : $1 \mathrm{~kg}$ gel lidah buaya) dimasukkan ke dalam bak adonan.

- Menghidupkan listrik atau genset untuk mengaduk campuran adonan.
- Pengadukan $\pm 1 / 2$ jam.

- Mematikan listrik atau genset, kemudian adonan siap dicetak dan dipotong

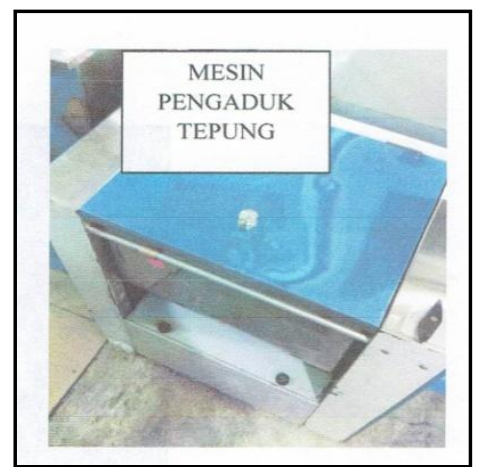

Gambar 3. Bantuan mesin Pengaduk Tepung

c. Penyuluhan atau Sosialisasi P-IRT, Merk Dagang dan Kandungan Gizi/Kimia

Hal yang perlu disiapkan sebelum produk dikemas adalah ijin dari Dinas Kesehatan atau lebih dikenal dengan P-IRT. Ijin usaha di bidang industri makanan bagi industri rumah tangga atau UKM adalah PIRT atau Produksi Pangan Industri Rumah Tangga yang dikeluarkan oleh Dinas Kesehatan setempat.

Kelompok Tani Lidah Buaya Kita RW 04 telah mendapatkan Sertifikat Penyuluhan dari Dinas Kesehatan Kota Pekanbaru Nomor : 1713/1471/15. Produk kerupuk lidah buaya telah mendapat Sertifikat Produksi Pangan Industri Rumah Tangga (P-IRT) dan produk teh lidah buaya dengan sertifikat Dinkes PIRT Nomor : 2061471020547-20.

Semua produk olahan lidah buaya produksi Kelompok Tani Lidah Buaya Kita diberi merk dagang bernama TIGHE. Merk Dagang TIGHE merupakan rancangan dari mitra kelompok tani lidah buaya.

Uji kandungan gizi/kimia dilakukan oleh Balai Pengkajian dan Penerapan Teknologi (BBPT) Serpong pada tanggal 6 Juni 2016. Dari hasil uji proksimat terhadap produk lidah buaya maka didapatkan kadar air 11 , $17 \%$, kadar abu 2,74\%, kadar lemak 0,227\%, kadar protein 3,73\% dan karbohidat 82,3\%. sedangkan uji aktifitas antioksidan pada produk teh lidah buaya adalah 42,997 atau setara dengan 3782,811 setara $\mathrm{Ug} / \mathrm{g}$ BHA 


\section{d. Pelatihan pengemasan dan promosi produk}

Pelatihan pengemasan produk dilaksanakan pada tanggal 20 Agustus 2016 di RW 04, Kelurahan Lembah Sari, Kecamatan Rumbai Pesisir, Kota Pekanbaru. Bahan dan alat yang digunakan untuk mengemas produk kerupuk lidah buaya adalah plastik, kertas merk TIGHE ukuran $14 \times 12 \times 6 \mathrm{~cm}$, isolasi bening, timbangan dan mesin pengepres, sedangkan untuk mengemas produk teh adalah gunting, baki, plastik, timbangan, pembungkus aluminium foil ukuran $11 \times 17 \mathrm{~cm}$, kertas label dan alat pengepres.

Pengemasan produk kerupuk lidah buaya adalah sebagai berikut : kerupuk lidah buaya yang telah siap kemas ditimbang dengan menggunakan timbangan seberat 250 gram, kemudian dimasukkan kedalam plastik ukuran $15 \times 25 \mathrm{~cm}$ dan dikemas dengan menggunakan mesin pengepres. Kerupuk TIGHE yang sudah dikemas kemudian dimasukkan dalam ukuran kotak berbahan kertas glossy sehingga terkesan eksklusif dan dapat dijadikan sebagi oleh-oleh khas Pekanbaru. Teh Lidah Buaya dikemas langsung ke dalam plastik kemasan aluminium foil, kemudian diberi label.

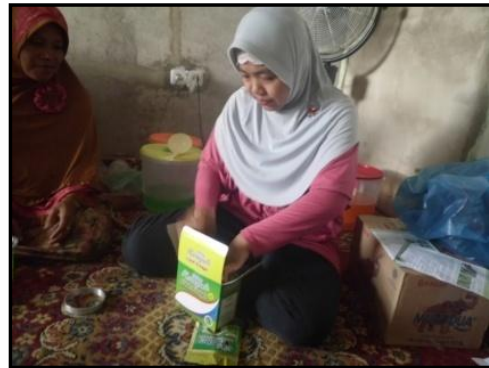

Gambar 4. Pengemasan kerupuk lidah buaya

Pelatihan teknik pengemasan minuman lidah buaya dilakukan secara demostrasi dengan cara memasang gulungan plastik penutup gelas ke bagian atas alat pengepres dan menyiapkan gelas plastik yang sudah diisi minuman dibawahnya. Alat pengepes yang sudah dihubungkan dengan arus listrik kemudian ditekan tombol on untuk mendapatkan panas sesuai yang diinginkan, setelah lampu indikator menyala dan suhu mesin sudah menunjukkan angka $170^{\circ} \mathrm{C}$ maka pengepresan siap dimulai dengan cara menekan tangkai pengepres ke bawah.

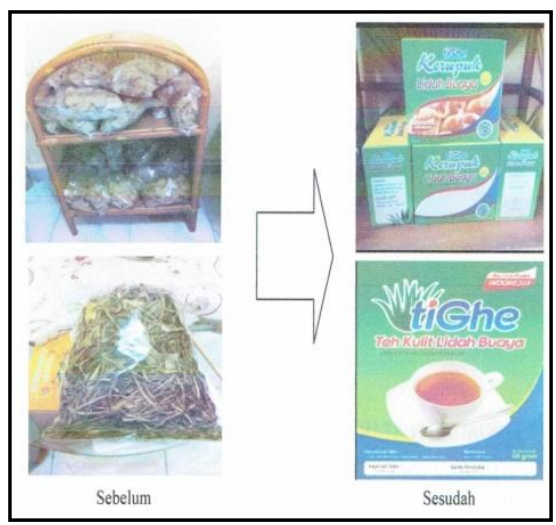

Gambar 4. Kerupuk dan Teh sebelum dan sesudah dikemas

Produk kerupuk dan teh yang semula masih dikemas dalam plastik, belum mempunyai merk dagang dan menjual produk di rumah dan pemasaran sebatas lingkungan sekitar, kini kerupuk dan teh lidah buaya sudah dikemas menarik dengan mencantumkan ijin P-IRT, merk dagang dan kandungan gizi/kimia sehingga dapat dipasarkan di toko oleh-oleh dan minimarket (swalayan).

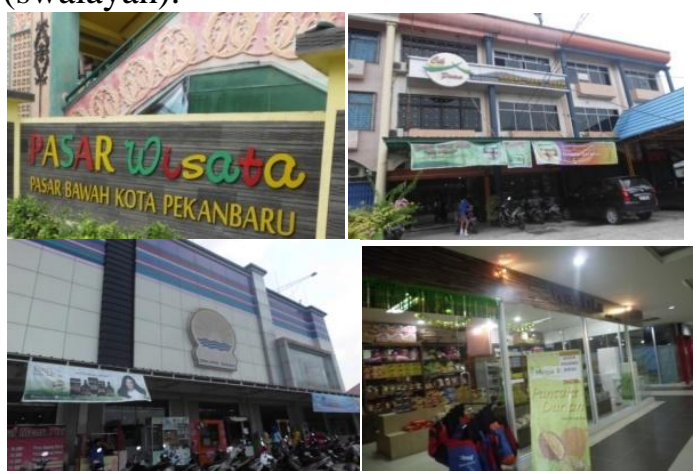

Gambar 5. Toko oleh-oleh yang menjual poduk TIGHE

Kerupuk dan teh lidah buaya dapat dijumpai di toko oleh-oleh "Kartika" lantai 1, Bandara Sultan Syarif Hasyim Pekanbaru, toko oleh-oleh "Cik Puan II" Jl Jendral Sudirman Pekanbaru, Pasar Wisata, Toko Oleh-oleh H Sabar. Pasar Bawah Kota Pekanbaru dan swalayan Hawai Jl Yos Sudarso Pekanbaru.

Dengan berkembangnya teknologi informasi saat ini, produk TIGHE kini 
juga memanfaatkan sosial media instagram aloevera_pekanbaru, twitter @lidahbuayakita dan facebook lidah buaya kita sebagai sarana pemasaran produk.

\section{e. Pelatihan Analisis Usaha}

Kegiatan analisis usaha yang dilakukan meliputi (1) membuat rekapitulasi biaya yang dikeluarkan untuk operasional usaha, (2) membuat rekapitulasi penerimaan usaha baik dari pendapatan pokok maupun sampingannya dan (3) menghitung harga pokok dan keuntungan.

Pelatihan analisis usaha minuman lidah buaya dilakukan dengan menghitung biaya operasional saja karena minuman lidah buaya diproduksi berdasarkan pesanan konsumen seperti pada acara-acara arisan, pesta pernikahan dan lain-lain sehingga biaya produksi langsung dapat diperhitungkan pada saat pesanan selesai diproduksi.

Biaya produksi minuman lidah buaya dihitung dengan cara membagi jumlah biaya operasional yang dikeluarkan untuk pesanan dengan jumlah unit produk minuman yang dihasilkan dalam pesanan bersangkutan. Agar mendapat keuntungan Rp. 122.800,maka minimal minuman yang harus dipesan adalah 50 gelas, dengan asumsi bahwa harga minuman pergelas adalah Rp. 5.000,-. Ilustrasi biaya operasional untuk membuat minuman lidah buaya dapat dilihat pada tabel1 berikut :

Tabel 1. Biaya operasional pembuatan minuman lidah buaya.

\begin{tabular}{|c|c|c|c|c|}
\hline No & Keterangan & Jumlah & Harga (Rp) & Biaya $(\mathrm{Rp})$ \\
\hline 1 & Pelepah Lidah Buaya $(\mathrm{kg})$ & 5 & 5.000 & 25.000 \\
\hline 2 & Gula (kg) & 1 & 15.000 & 15.000 \\
\hline 3 & Essence/Sirup $1 \mathrm{btl} / 500 \mathrm{ml}$ & 0,5 & 25.000 & 12.500 \\
\hline 4 & Vanili (buah) & 1 & 1.000 & 1.000 \\
\hline 5 & Daun Pandan (ikat) & 1 & 1.000 & 500 \\
\hline 6 & Garam (gram) & 0,1 & 2.000 & 200 \\
\hline 7 & Air (galon/10 liter) & 0,5 & 20.000 & 10.000 \\
\hline 8 & Gas (kg) & 0,4 & 25.000 & 5.000 \\
\hline 9 & Gelas cup (1 set@50 bh) & 1 & 15.000 & 15.000 \\
\hline 10 & Sablon ( 1 rol 4x) & 0,3 & 50 & 15.000 \\
\hline 11 & Listrik (kwh) & 70 & 400 & 28.000 \\
\hline \multicolumn{2}{|c|}{ Biaya Total } & & & 126.200 \\
\hline \multicolumn{2}{|c|}{ Produksi Minuman Lidah Buaya } & 50 & $@ 5.000$ & 250.000 \\
\hline \multicolumn{2}{|c|}{ Keuntungan per 50 kotak } & & & 122.800 \\
\hline
\end{tabular}

Harga pokok kerupuk lidah buaya per1 kotak atau@250 gr dapat dilihat pada tabel 2 berikut :

Tabel 2. Perhitungan harga pokok kerupuk lidah buaya

\begin{tabular}{|c|c|c|c|c|c|}
\hline No & \multicolumn{4}{|c|}{ Keterangan } & Biaya (Rp) \\
\hline 1 & \multicolumn{4}{|l|}{ Biaya bahan baku } & 675.200 \\
\hline 2 & \multicolumn{4}{|l|}{ Biaya tenaga kerja } & 400.000 \\
\hline 3 & \multicolumn{5}{|l|}{ Biaya overhead } \\
\hline & \multicolumn{5}{|c|}{ a.Penyusutan peralatan per bulan } \\
\hline & '- Pisau & 2 buah & @Rp. 100.000,- & $12 \mathrm{bln}$ & 16.667 \\
\hline & '- Blender & 1 buah & @Rp. 350.000, & 24 bln & 14.583 \\
\hline & - Kompor Gas & 1 buah & @Rp. 400.000, & 36 bln & 11.111 \\
\hline & - Dandang & 1 buah & @Rp. 150.000, & $48 \mathrm{bln}$ & 3.125 \\
\hline & - Panci & 1 buah & @Rp.75.000, & $48 \mathrm{bln}$ & 1.563 \\
\hline & "Tampah & 5 buah & @Rp. 30.000, & 24 bln & 6.250 \\
\hline & '- Pengepres & 1 buah & @Rp. 400.000, & 36 bln & 11.111 \\
\hline & '- Timbangan & 1 buah & @Rp. 150.000, & $36 \mathrm{bln}$ & 4.167 \\
\hline & - Telenan & 1 buah & @Rp. 30.000, & $12 \mathrm{bln}$ & 2.500 \\
\hline & '- Pelabelan & 1 buah & @Rp. 100.000, & $24 \mathrm{bln}$ & 4.167 \\
\hline & b. Listrik & & & & 5.000 \\
\hline & c. Transportasi & & & & 4.000 \\
\hline & Total overhead & & & & 84.243 \\
\hline & Biaya & & & & 1.159 .443 \\
\hline & ah Produksi & & & & 64 \\
\hline & a Pokok & & & & 18.116 \\
\hline
\end{tabular}

Penelitian BBPT menyatakan bahwa dalam kulit lidah buaya TIGHE yang sudah dikeringkan mengandung $42,9 \%$ antioksidan yang bermanfaat bagi tubuh. Kulit lidah buaya dari proses pembuatan kerupuk dimanfaatkan sebagai teh lidah buaya, dimana $4 \mathrm{~kg}$ pelepah lidah buaya dapat menghasilkan 100 gr teh lidah buaya kering, sehingga produksi teh lidah buaya kering \pm 400 g/bulan.

Teh lidah buaya dikemas dalam aluminium foil berbentuk kantong kemasan seberat 25 gr. Biaya yang dikeluarkan untuk pembuatan kantong kemasan berbahan aluminium foil $\mathrm{Rp}$. 5.250,- dan sticker Rp. 1.500,- sehingga biaya kemasan adalah Rp.6.750,-. Saat ini teh lidah buaya dijual dengan harga Rp. 15.000,- per kantong kemasan sehingga keuntungan dari penjualan teh lidah buaya per kantong kemasan adalah Rp 8.250,-

\section{f. Evaluasi dan pendampingan}

Hasil evaluasi menunjukkan bahwa setelah peserta mengikuti pelatihan membuat minuman lidah buaya, tingkat pengetahuan peserta meningkat menjadi 52\%. Yang menjadi kendala dalam pembuatan minuman 
lidah buaya adalah jangka waktu konsumsi yang singkat. Produk minuman es lidah buaya ini hanya bisa dipesan dan langsung di konsumsi. Namun demikian Tim Ibm memberikan bantuan alat pengepres gelas agar minuman tidak tumpah.

Bantuan mesin pengaduk tepung merupakan solusi dalam mengatasi kendala pengolahan adonan tepung untuk meningkatkan kapasitas produk kerupuk lidah buaya sebesar $3 x$ dari produksi semula dengan waktu lebih cepat yaitu $1 / 4$ kali.

Sesudah pelatihan pengemasan, tingkat pengetahuan peserta meningkat menjadi $56,67 \%$, Peserta mengetahui apa saja yang harus ada dalam label kemasan seperti merk,P-IRT dan kandungan gizi/kimia. Peserta juga terampil dalam mengemas minuman, kerupuk dan teh lidah buaya.

Pada kegiatan analisis usaha, mitra telah melaksanakan pembukuan terhadap semua komponen biaya dan penerimaan, perhitungan harga pokok produksi dan keuntungan.Dalam menjual produknya, mitra telah menjual dengan dengan harga yang telah disesuaikan dengan harga pada saat pelatihan analisis usaha dimana untuk harga satu gelas minuman lidah buaya adalah $\mathrm{Rp}$. $5.000,-$, satu kotak kerupuk 250 gr adalah $\mathrm{Rp}$ $20.000,-$ dan satu kantong teh 25 gr adalah Rp. 15.000,-. Keuntungan yang diperoleh mitra dengan harga yang disebutkan diatas yaitu minuman lidah buaya sebesar Rp. $122.800,-/ 50$ kotak atau Rp. 2.456,- per gelas, kerupuk sebesar Rp.1.884,-/kotak dan teh sebesar Rp. 8.250,- per kantong

\section{KESIMPULAN}

Kesimpulan yang dapat disampaikan adalah sebagai berikut :

1. Mitra mampu mengolah lidah buaya menjadi minuman lidah buaya dan terampil dalam mengemas minuman lidah buaya.

2. Mitra memiliki alat untuk menunjang proses produksi diantaranya mesin pengepres gelas plastik dan mesin pengaduk tepung.

3. Produk mitra telah diuji kandungan gizinya, mempunyai merk dan ijin PIRT.
4. Mitra mampu mengemas produk minuman, kerupuk, dan teh lidah buaya dengan kemasan menarik sehingga siap dipasarkan.

5. Mitra mampu mempromosikan produk minuman, kerupuk dan teh lidah buaya.

6. Mitra mampu membuat analisis usaha dengan cara pembukuan sederhana dan menetapkan harga pokok sehingga dapat diketahui keuntungan yang diperoleh.

\section{UCAPAN TERIMAKASIH}

Ucapan Terimakasih kepada Kemenristek Dikti yang telah memberikan pembiayaan skim Ipteks bagi Masyarakat (IbM) No. SP DIPA-042.06.1.401516/2016 tanggal 7 Desember 2015 sesuai dengan Surat Perjanjian (kontrak) Penugasan Dalam Rangka Pelaksanaan Program Pengabdian Kepada Masyarakat (Mono) Tahun Anggaran 2016 Nomor : 010/Unilak-LPPM/B.07/2016 tanggal 29 Februari 2016.

\section{REFERENSI}

1. Ayodya, Wulan, 2010. Cara Jitu Hitung Modal Usaha.PT Elex Media Komputindo. Kompas Gramedia. Jakarta.

2. Purwaningsih, Dyah.2015.Prospek dan Peluang Usaha Pengolahan Produk Aloe vera $L$. Jurdik Kima Universitas Negeri Yogyakarta.

3. Ramadhina, Aprilinda dan Islandscript, 2011. Kursus Kilat menguasai SPSS untuk UKM. PT Elex Media Komputindo. Kompas Gramedia. Jakarta.

4. Simanungkalit. Agus Riyan. 2014. Analisis Keuntungan dan Skala Usaha Tani Hortikultura Aloe vera (Lidah Buaya) di Kota Pontianak. Fakultas Ekonomi dan Bisnis Universitas Diponegoro. Semarang.

5. Soewitomo, Sisca. 2012. Resep Minuman Dingin dan Segar Ala Sisca Soewitomo. Gramedia Pustaka Utama. Kompas Gramedia. Jakarta.

6. Suhendro Pristi, Sagala Prihatiningsih. September 2013. Penyuluhan Budidaya Lidah Buaya Sebagai Bahan Baku Alternatif Dodol Bengkel di Desa Bengkel Serdang Bedagai. Jurnal 
Pengabdian Kepada Masyarakat Vol.19 Nomor 73. Tahun XIX September 2013.UNIMED. Universitas Negeri Medan. Medan.

7. Sukapto, Paulus, Arthaya, B.M., Aritonang, Kinley. Sandy, Ignatius dan Nainggolan M. 2014. Pemberdayaan Usaha Kecil Rumput Laut Aulia Sari di Keluarahan Majahleha.Kecamatan Rancasari. Bandung. Laporan Pengabdian. Lembaga Penelitian dan Pengabdian kepada Masyarakat. Universitas Khatolik Parahyangan. Bandung.

8. M.Yurisithae Erlinda, Dolorosa Eva, Muani Ani, Januari 2012. Analisis faktor-faktor yang mempengaruhi produksi usaha tani lidah buaya di sentra produksi kota Pontianak Provinsi Kalimantan Barat. Jurnal Ipteks - Ilmu Pengetahuan dan Rekayasa. POLNEP. Pontianak. 